\title{
HUNGARIAN INTERNATIONAL NEW VENTURES - MARKET SELECTION AND THE ROLE OF NETWORKS IN EARLY INTERNATIONALISATION
}

\author{
${ }^{1}$ MIKLÓS KOZMA - ${ }^{2}$ MAGDOLNA SASS ${ }^{1}$ \\ ${ }^{1}$ Department of Business Economics, Corvinus University of Budapest, Hungary \\ ${ }^{2}$ Center for Economic and Regional Studies, Hungarian Academy of Sciences, Budapest, Hungary \\ Email: sass.magdolna@krtk.mta.hu
}

\begin{abstract}
In this article we rely on the concept of "international new ventures" (INV), and concentrate on the analysis of two research propositions in the case of selected Hungarian INVs, based on company interviews in two selected industries, biotechnology and information technology. First, we analyse the criteria of the selection of foreign markets in the internationalisation of these firms and second, the role of networks in the internationalisation process of selected Hungarian INVs. Our results highlight the typical internationalisation pattern of targeting the largest developed foreign markets globally. In terms of the role of networks in internationalisation, we found evidence of the decisive role of networks in all cases examined. The personal network of the founder(s) was emphasised, especially in winning early clients. The scalability of the personal network-based business model was, however, questioned. The management implications of our findings suggest Hungarian INVs need to intensify their involvement in international communities supporting the growth of such companies. Areas for potential future research include comparing our findings with empirical results from other countries in Central-Eastern Europe.
\end{abstract}

Keywords: international new ventures, innovative industries, Hungary, market selection, networks

JEL-codes: F23, L14

Magdolna Sass's research was supported by the Hungarian Research Fund, NKFIH (grant no. 109294). The authors are grateful for the helpful comments of two anonymous referees. 


\section{INTRODUCTION}

An increasing number of business news, reports and articles document and analyse the existence and characteristics of companies in Central and Eastern Europe, which soon after their establishment began growing and/or internationalising very rapidly (see for example Jarosińki 2014; Zbierowski 2014; Sliwinski - Sliwinska 2014; Nowinski - Rialp 2013; Kiss et al. 2012; Lamotte - Colovic 2015; Danik et al. 2016; Vissak 2007). There have been such cases reported in Hungary as well (Czakó - Könczöl 2014; Békés - Muraközy 2012; Némethné Pál 2010), and a few "born global" firms have also been identified (Sass 2012; Szalavetz 2015).

In the present article we rely on the concept of "international new ventures" (INV) and based on company interviews in two selected industries, we concentrate on the analysis of two research propositions in the case of selected Hungarian INVs. First, we analyse the criteria of the selection of foreign markets in the internationalisation of these firms and second, the role of networks in the internationalisation process of selected Hungarian INVs.

The article is structured as follows. First, we present the theoretical background and the most important related results of the literature. Second, we present our research questions and then give a brief description of the methodology applied including the sample of companies used. This is followed by the analysis of the collected data, and the final section concludes.

\section{THEORETICAL BACKGROUND AND EXISTING EMPIRICAL RESULTS}

An INV is defined as "a business organization that, from inception, seeks to derive significant competitive advantage from the use of resources and the sale of outputs in multiple countries" (Oviatt - McDougall 1994). The internationalisation of these firms is rapid (McDougall et al. 1994; Sapienza et al. 2006; Matiusinaite - Sekliuckiene 2015; Schwens - Kabst 2009; Madsen 2013; on the CEE-experience: Jarosiński 2013; Lamotte - Colovic 2015; Zapletalová 2015; Ciszewska-Mlinaric et al. 2016; Musteen et al. 2014) compared to other companies, which internationalise gradually (Johanson - Vahlne 1977; Eriksson et al. 1997; Vissak 2003). Internationalisation is most often defined as exporting (Fan - Phan 2007); in certain cases, foreign direct investments are added. Industry factors play an important role in the case of INVs: they usually shape the process of internationalisation and the strategic choices of INVs to a great extent (Andersson et al. 2014). This can be underlined by the fact that INVs are usually concentrated in industries with high technological intensity, niche technology or in knowledge-based activities (Autio et al. 2000; Oviatt - McDougall 2005; 
Johnson 2004; Welch 2015). Besides commonalities of the internationalisation process of INVs, it is important to note on the basis of the findings of Verbeke et al. (2009) that the actual internationalisation process of a firm is highly context specific. Thus - besides similarities - we can also find relatively large differences in the process of internationalisation of INVs.

We rely on two main branches of the literature on INVs in our analysis of the two topics we concentrate on. First, due to globalisation, foreign markets are becoming more homogeneous, thus companies, mainly those active in high tech industries, can internationalise from the start (from their establishment) in niche markets (see e.g. Jolly et al. 1992; Oviatt - McDougall 1994; Knight - Cavusgil 2004; Baum et al. 2011). Because of the increased homogeneity of markets, their internationalisation is less constrained geographically compared to staged internationalisers. Thus, they can reach out quickly to international markets, including to faraway destinations and in our opinion are less constrained by the level of foreign trade liberalisation as opposed to staged internationalisers. The second line of literature addresses the role of networks in internationalisation. According to that, markets are considered as networks of relations, in which firms are connected to each other by various and complex links; these relations provide opportunities for learning, establishing contacts and building trust and commitment (Eriksson et al. 1997; Coviello - McAuley 1999; Johanson - Vahlne 2003 and 2011; Vissak 2004). In our opinion, INVs, due to their specific nature, may be more inclined, as opposed to staged internationalisers, to take part in various networks, which then helps their internationalisation.

Our analysis concentrates on Hungarian INVs. The presence of INVs and born globals in the post-socialist economies of Central and Eastern Europe (CEE) is evidenced and examined by various papers. For example, Nowinski and Rialp (2013) list certain "region-specific" characteristics of CEE INVs. They underline that these firms are constrained not only by limited financial resources (see e.g. Kiss et al. 2012) but also by relatively low human and social capital. Furthermore, they show that there are certain region-specific drivers of early internationalisation, such as domestic market entry barriers and highly solvent markets present in developed economies. They also underline the role of networks: while first the entrepreneurs rely on their domestic networks, parallel with international expansion, they develop their international networks as well. Another interesting and specific feature of CEE INVs may be their resource saving strategies and operations, a behavioural pattern inherited from the shortage economy, which may form part of a competitive advantage specific to the CEE region's firms (cf. Ciszewska-Mlinaric et al. 2016). Danik et al. (2016) called attention to the possible differences in the geographical targets and scope of internationalisation as well as inclination to and areas of innovation among CEE INVs, based on 
Polish and Czech cases. In this, possibly, the strength of bilateral economic relations between the home and host countries and the presence of diaspora can play a role.

There is an emerging literature focused specifically on Hungarian INVs. For example Sass (2012) shows that born globals are present in the Hungarian medical precision instruments industry. Their internationalisation success is based on their innovativeness, which is partly a heritage from the break-up of large stateowned companies in the industry, partly related to strong R\&D activity in the field in Hungarian universities. Szalavetz (2015) analysed in detail one Hungarian company case, emphasizing the importance of industry-specific factors, "deviating" and delaying the internationalisation of a potential born global firm.

\section{RESEARCH PROPOSITIONS}

In our article, we concentrate on two important characteristics of INVs and analyse these in detail based on Hungarian company cases.

\subsection{Geographical scope of internationalisation}

First, the literature on INVs emphasizes the rapid internationalisation of these firms, with different geographical scope. For example, in one of the first seminal articles, which introduced the notion of INVs (Oviatt - McDougall 1994), four types of INVs were distinguished, in the case of which the geographical scope of internationalisation differed significantly. In the case of New International Market Makers, the main ownership advantage lies in the ability to identify imbalances between countries and create markets where they have not existed beforehand. Thus, this type of INVs depend on their target markets to a great extent, the geographical scope of internationalisation is basically pre-determined by the characteristics of the potential markets. They can be either Export/Import StartUps or Multinational Traders. In the case of Geographically Focused Start-Ups, as their name indicates, these firms address a specialised need of a particular region or country through the use of foreign resources. Here again, the characteristics of the geographical target market are of special importance. As far as the fourth type of INVs is concerned, Global Start-Ups have much less "stickiness" in terms of their host countries: their choice of location in the process of internationalisation is geographically unlimited. We think that Global Start-Ups may be present mainly in innovative industries with increasing global demand, such as our analysed industries, biotechnology and IT. 
As mentioned, INVs are active in technology intensive industries. High-technology products appear to be quite "global", they need little local adaptation (Andersson 2004) and they can be highly standardised, thus they can be sold basically immediately in any country, where a viable demand for the product is present, where (potential) customers are located (Bell 1995). This process has been helped to a great extent by globalisation, which made markets around the world increasingly homogeneous. Thus, the psychic distance for these products is considerably reduced (Evers 2010). Furthermore, new technological developments and the emergence of the internet as a transport channel enabled new industries to transfer their products to faraway locations, thus reducing further the geographical limitedness of international operations. In addition, given the nature of their industry and product, INVs usually target relatively small niche-markets and have geographically spread lead markets around the world. They define their customer groups and are highly customer-oriented (Rialp et al. 2005). Thus, we can say that they are geographically unlimited, as they follow their customers proactively. In certain cases, they are even forced to do so: given the small size of niche-markets, they need to reach a certain threshold level of sales (including exports) to be profitable, for which the home market may not be large enough (for example, the size of the home country is a significant explanatory factor for the internationalisation of a new venture in Fan - Phan 2007). Furthermore, the relatively low level of competition in niche-markets and the aim to capitalise on the specific knowledge on which the ownership advantages of the INV are based, induces the firm to internationalise rapidly in each reachable market. As a result, in terms of the geographic scope of internationalisation, INVs usually reach a broader scope compared to other companies.

How can we define and compare the geographical scope of the internationalisation of INVs? The distance of host and home countries - besides the modes of entry - is one of the two major dimensions of the internationalisation process of the firm (Jones - Coviello 2005). The geographical scope of a company can be measured by the number, geographical spread and diversity of its foreign markets (Hashai 2011).

Based on the above, in our first proposition we focus on understanding the geographical scope of internationalisation of a specific sample of INVs as follows.

Proposition \#1: For Hungarian INVs operating in knowledge-intensive industries, the primary target markets for internationalisation are niche-markets in highly developed economies. 


\subsection{Network perspective on internationalisation}

The network perspective on internationalization of firms is related to organisational and political science approaches. Here the importance of relations between companies is emphasized, as a result of which a network is created. These relations may take several forms, and may include social, economic, legal and technological exchanges between the companies. They can rely on personal contacts between company managers. They can be formal and informal as well. They can exist prior to the establishment of the company in the form of personal networks of the founders.

In a theoretical paper, Vissak (2004) summarises her findings on the network approach to internationalisation, highlighting, among others, the relevance of the approach in terms of going beyond the traditional internationalisation models, describing business realities and context well, as well as the approach's suitability to explain the selection of foreign markets and the process how resources necessary for internationalization can be acquired through network relationships.

In their seminal work, Oviatt and McDougall (1995) state that INVs possess strong international business networks. Also other empirical and theoretical studies emphasize the importance of networks enabling newly established firms to internationalise (see for example Bell 1995; Fillis 2002; or Rialp et al. 2005). Coviello and Munro (1995) showed that network relationships are of fundamental importance in accelerating access and entry into new foreign markets in the case of quickly internationalising firms. Furthermore, network relationships are important from the point of view of the growth of the company, and they actively influence the pattern of internationalization in terms of foreign market selection and entry. In addition, Chetty and Blankenburg Holm (2000) emphasise the importance of organically developed networks in explaining the dynamics of how firms cooperate with their network partners to extend, penetrate and integrate their international markets. They conclude that involvement in such interactions support the firms in obtaining new opportunities and knowledge, and enjoy the benefits of pooled resources. Coviello and Munro (1997) show that small firms invest heavily in their network relationship in order to enhance their international market development. Chetty and Campbell-Hunt (2004) denote the networking strategy of quickly internationalising, born global firms as "aggressive" compared to slower and late internationalisers. Contrastingly, the network context also bears limitations on how businesses operate. Johanson and Vahlne (2011) highlight that firms operating in an international business environment need to make sure they respect the interest of their partners in the network and "prepare for action, not necessarily known on beforehand" (Johanson and Vahlne 2011: 489). 
Notwithstanding the prolific literature on the importance of networks in internationalisation, certain analyses found a negligible role of networking for quickly internationalising SMEs and born globals (see e.g. Kalinic - Forza 2012). Rasmussen et al. (2001) noted that in the case of certain INVs there is no previous network involvement of the founder prior to internationalisation.

In terms of the empirical results of investigating the relevance of networks in the internationalisation of firms in the CEE region, Daszkiewicz (2014) performed a survey of over 200 internationalised enterprises in Poland in 2013-2014, looking for statistical relationships between internationalisation motivations and operating in networks. She found that there was a statistically significant relation between firms operating in networks and the main motives for internationalisation according to Dunning's typology of internationalisation motives (Dunning 1993), but no statistically significant relationship according to the OECD internationalisation motive typology (OECD 1997a; 1997b). In addition, she found that operating in networks was related to the firms' knowledge of the foreign markets and the actual strategy they followed. Meanwhile, based on a Hungarian sample of case studies of 10 small-and-medium enterprises, Czakó and Könczöl (2014) concluded that notwithstanding the limitations of the research methodology, there is evidence that the SMEs - founded in the 1990s or later - show the characteristics of the network-based internationalisation pattern of Johanson and Vahlne (2009).

In light of the above, the theoretical and mainly empirical literature does not provide conclusive evidence concerning the role of networks in the internationalisation of INVs in the CEE region and further afield. We constructed our second proposition around this dilemma as follows.

Proposition \#2: Participation in networks (in a wide sense) plays an important role in the internationalisation process of Hungarian INVs operating in knowledge-intensive industries.

\section{METHODOLOGY - OUR SAMPLE}

We prepared company case studies based on semi-structured, questionnairebased interviews with the founders of Hungarian INVs. We identified companies in the IT and biotechnology industries, which may comply with the definition of INVs. This approach is widely used in the research of the internationalisation of firms, born globals and international new ventures (see e.g. Vissak 2010). We did not claim to build a representative sample of the population of Hungarian INVs; 
the focus on knowledge-based industries was used, however, to narrow down the group of firms, which may be INVs.

Our methodology has the advantages of being able to provide detailed information about the operation and internationalisation of the selected firms. On the other hand, as a disadvantage, the small and not randomly selected sample reduces the scope for generalisation of our analytical results. Table 1 contains information of selected important characteristics of the companies in our sample. We conducted interviews with 6 firms, two biotech and four IT firms. Five out of six firms have less than five years of history. They all internationalised within 1 year.

Table 1. Our research sample

\begin{tabular}{|c|c|c|c|c|c|c|}
\hline 离 & 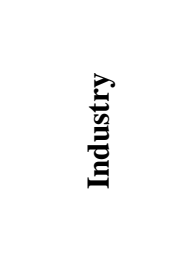 & 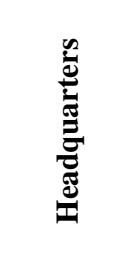 & 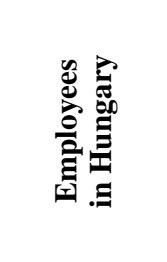 & 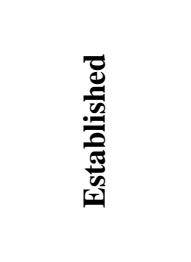 & 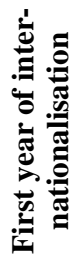 & 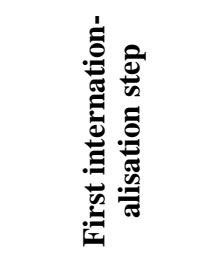 \\
\hline $\mathrm{A}$ & biotechnology & Budapest & 35 & 1990 & 1990 & export \\
\hline $\mathrm{B}$ & $\begin{array}{l}\text { biotechnology } \\
\text { (with high IT } \\
\text { content) }\end{array}$ & Budapest & 17 & 2011 & 2012 & $\begin{array}{l}\text { cooperation with } \\
\text { US universities }\end{array}$ \\
\hline $\mathrm{C}$ & IT & Budapest & 6 & 2015 & 2015 & export \\
\hline $\mathrm{D}$ & IT & Budapest & 20 & 2014 & 2014 & export \\
\hline $\mathrm{E}$ & IT & Budapest & $\begin{array}{c}7 \text { (until } \\
\text { acquisition) }\end{array}$ & $\begin{array}{c}2012 \\
\text { (sold in 2015) }\end{array}$ & 2013 & $\begin{array}{l}\text { export, local } \\
\text { agents }\end{array}$ \\
\hline $\mathrm{F}$ & IT & Budapest & $\begin{array}{c}10 \text { (until } \\
\text { acquisition) }\end{array}$ & $\begin{array}{c}2012 \\
\text { (sold in 2014) }\end{array}$ & 2012 & export \\
\hline
\end{tabular}

Source: compilation of the authors based on company interviews

\section{ANALYTICAL FINDINGS}

While a number of issues were raised and discussed in our semi-structured interviews, we focused our analysis on the two propositions of our research. The analytical findings below reflect particular elements of our propositions and allowed us to refine our understanding of the subject.

\subsection{Market selection}

First, we intended to understand better, and potentially refine, the phenomenon we identified in our first proposition reflecting our expectations based on literature findings: "For Hungarian INVs operating in knowledge-intensive industries, 
the primary target markets for internationalisation are niche-markets in highly developed economies".

Our sample included companies from knowledge-intensive industries, which may explain the fact that our proposition was confirmed by the sample with one exception (an IT firm): it provides services in Hungary and 3 neighbouring countries only. For all other firms, exports to developed countries are dominating in total sales. The outlier firm's original strategy was oriented on replicating a business model already successful globally to the region, where they could be first movers, and spread quickly in the neighbouring countries. Not surprisingly, a few years later, they were acquired by one of the major global players in the industry.

The general reason to choose major developed markets in the early stage of internationalisation is that product prices and service fees are higher in these markets, while Hungarian wages are lower. Another reason for an INV to go to the largest developed markets is that the scalability of the business is greater in major markets, and the potential growth of the business is attractive for the investors who finance the internationalisation process.

"The company was established for the world market: they do not sell on the Hungarian market - there would be only one potential buyer, because of the "nicheness" of the market, with this they have a good personal and scientific relationship - but no market relationship." (Interview with company B)

Thus company B in our sample resembles to a great extent to the "Global Start-Up" category of Oviatt and McDougall (1994). The next interview excerpt puts company D in the same category.

"We did not start our business for the Hungarian market. We have issues with the current state of Hungarian business culture, and also the market is not lucrative enough. Software development is not a location specific business anyway." (Interview with company D)

All the more, our interviewees reported a diminishing gap between the level of expectations in technological quality in developed countries and in Hungary. Hence, the quality of services INVs need to perform is relatively similar, while the purchasing power and disposable income are much higher in major developed markets. In that perspective there is no surprise that most INVs choose these markets in the early stage of their internationalisation.

Early stage INVs usually target a niche in the major developed markets, as a niche can be more effectively targeted through customisation and online marketing using big data technology. Furthermore, if the marketing is more sharply tar- 
geted to a clearly defined segment, there is less noise in marketing communication amidst the general tendency that customers receive an overwhelming amount of messages on a daily basis.

"The company spotted a market niche and started to develop software for this. Through the software they established market contacts with many firms, who acquired the software, thus they could get a clear picture about the state of the market in that area. Based on that, the firm moved into production activities as well and started research cooperation with American universities." (Interview with company B)

If INVs still want to target not (only) large markets but also smaller countries, they can expect a different range of advantages and disadvantages. Local regulations are often challenging to be understood and the company's services need to be adapted to limitations that restrict the smooth business operations designed for the developed markets. There can be cultural issues as well, although our interviewees did not particularly feel that pain as they chose their international markets carefully. They confirmed, however, that operating in less developed, relatively new and less regulated markets may offer business opportunities beyond what can be managed in more developed, and at the same time more regulated markets.

Respondents who run their companies in Central and Eastern European markets noted that there are significant synergies between their operations in different countries in the same region. Cultural patterns are similar; hence the business model in one country need not be significantly different from the business model applied in a neighbouring country. There is also scope for joint administration and supporting functions to be operated in a central location in the region.

"There were synergies based on cultural similarities in the four regional countries we entered. We had personal contacts there, we knew the culture already, and we were introduced to local business partners. Our Hungarian business model was well scalable, which was vital, as the domestic market was not large enough for a sustainable business. However, all four countries were different in terms of regulations and we had to set up processes in parallel. At least at the beginning." (Interview with company F)

We did explicitly ask the fundamental question regarding what factors they considered when deciding on the markets to target in the early stage of their internationalisation. While our examination is primarily of qualitative nature, we could synthesise the most common responses into a short list of decision criteria: size of market (potential income), maturity of market (growth potential), geographical distance, cultural distance, existence of local contact or representative 
(access to networks), and level of competition (if there is first mover advantage). We concluded that there were no surprises in that list, compared to what the usual considerations were in the cases covered by existing international business literature.

\subsection{The role of networks in internationalisation}

Our other focus of interest was reflected in our second proposition: "Participation in networks (in a wide sense) plays an important role in the internationalisation process of Hungarian INVs operating in knowledge-intensive industries". We were keen to understand this expected phenomenon better, and were looking for ways to further specify our findings.

There was unanimous support for the answer that the personal network and knowledge of the founder(s) played a key role in winning early clients. Our interviewees did not develop their product before they had an understanding of the markets they would target, while their knowledge of the target market and the needed product stemmed from their personal relationships in the region. It was mentioned that overcoming the initial lack of trust in a particular market may be prohibitively difficult unless there are personal relationships that invoke trust supporting the early adoption of the INV's products. Apart from trust, accessibility to the market was also helped by the market knowledge of the founders and their local contacts.

"After privatisation, our activity was not interesting for the new owner, they let us go. We collected the base capital from our own money, established the firm, two directors jumped into a Lada car, and went to those Western European pharma companies, which we knew were interested in this activity and product. We came back with three contracts - and the others came later." (Interview with company A)

The scalability of the personal network-based business model was questioned in some of the interviews. INVs in our sample shared the ambition to scale up their activities in foreign markets early on; hence the issue of a business model overly reliant on the founders was raised in the interviews. While the personal relationships of the founders seemed to be a critical asset in bringing early adopters to the company, if additional sales were also built around the network of the founders, capacity issues arose before long. No single person can manage a network of client relationships beyond a certain scale, hence an organisation for professional client acquisition and client support was developed in most companies interviewed. 
"I have existing relationships in the new markets we target. However, this is not scalable; it cannot generate a good deal flow. New relationships come from our developing track record, through our venture capital partners, and conferences [...] This is a process; the company is less and less dependent on the founders." (Interview with company D)

A general phenomenon synthesised from interview findings is that the original idea of a product or a business concept usually came from the adaptation of international benchmarks or validating the idea through benchmarking. The founders of the companies interviewed, without exception, have studied or worked abroad prior to starting up their company. During their foreign stay they were impressed by different solutions and business models in a particular field and started thinking about how the concept could be applied in their home country. A less direct way of international benchmarking was also mentioned: the founders had the idea of a business and before they formally started organising the company, they searched for comparable international examples for validating the concept. While direct adoption of an international idea may not have always been possible, international benchmarks provided a useful frame of reference to keep the business in a direction supported by the success stories of comparable foreign companies.

The founders, as noted above, studied or worked abroad before starting their Hungarian company. This was useful not only for validating the idea but also this was the time when they developed their international relationships, the network of which later proved to be vital in their initial international sales activities. There seems to be no other effective way of nurturing an international network of relationships than through personal visits at an early stage during studies or early work experience.

When asked about how the networks can actually be developed and used for the benefits of the INV business, some interviewees highlighted the importance of listening skills. Integration into an international network, they said, is much less about promoting yourself or your idea to the targeted network, but more about going there and trying to learn from listening to the local opinion leaders. While earning trust is a key factor in the future utilisation of valuable foreign networks, trust can be more easily earned if the entrepreneur shows respect and pays attention to what topics arise in conversations, rather than trying to bring up topics of their choice.

Building networks, all the more, is a dynamic and ongoing process. Interviewees confirmed that the early business success they earned also generated additional contacts in the foreign markets they targeted. The relationship between network integration and business success, they claimed, was bidirectional, i.e. not only their early network relationships allowed initial business success, but their 
continued business success supported their further integration into the network, and also entering new markets through different networks.

Our more focused questions addressed the way entrepreneurs can integrate into relevant networks effectively and efficiently. We have learned that inbound marketing was one of the key tools that supported the credibility of founders at an early stage of their internationalisation. Inbound marketing aims to attract the attention of unrelated followers of a topic, usually online, hence an increased traffic on the entrepreneur's website or blog. Once a decent readership was established, the entrepreneur would be invited to join the targeted network. Conferences were confirmed to be a principal forum for meeting network members; hence a presentation opportunity at key conferences was often a milestone in the network integration for entrepreneurs.

"Inbound marketing is a ladder you climb. You share content, write blog posts and join conversation by listening to others. You enter interactions so that these may lead somewhere." (Interview with company C)

We have learned through our interviews that the local cultural conditions of foreign markets need to be understood for the INV to stand a reasonable chance of international success. Culture is a complex phenomenon, it is challenging and time-consuming to learn it well, therefore we asked the related question of how cultural learning can be achieved. Two fundamental answers were received. The first option for cultural learning is, not surprisingly, the personal visits of the founders in the foreign markets to be approached. In all cases examined, a certain period of frequent foreign visits was part of the internationalisation process, especially in the early stage of entering a market. The second option mentioned was hiring local representatives for the company, ideally before the actual market entry commenced. While finding a trustworthy and able local representative may prove to be a difficult challenge, the country choice of the INV can be influenced by the availability of a potential local representative in one country over another.

Interestingly, some of our interviewees mentioned that entrepreneurs are not left alone when they are willing to enter new markets or integrate into a network of relationships. The "startupper community" can actively provide opportunities for meeting likeminded entrepreneurs who try to help each other on a mutual basis. Introduction to a potential client or a local country representative, for example, are typical requests in the network. Fellow entrepreneurs are keen to respond to these requests as they expect that a similar helping hand will support them in the community sometime in the foreseeable future.

A typical way for an INV's early stage export is through contacting the local representatives of the potential clients, foreign companies. This is considered a 
more tractable approach than trying to liaise with the foreign headquarters of potential clients directly. Once the company's products achieve some success abroad, the direct integration into foreign networks becomes an opportunity on more reasonable terms.

One of our interviewees used an interesting concept called "nominal contacts". He referred to his acquaintances who, on paper, seem to be available to contact when support for the entrepreneur is needed. However, when the entrepreneur calls for their help, they do not seem to care enough to do anything beyond the most nominal gestures. Calling friends for information or introduction to potential clients are more than what they are ready to provide support in. Our interviewee highlighted the importance of having more meaningful personal relationships rather than "nominal contacts" who are unwilling to provide meaningful support when needed.

Some entrepreneurs went on to conclude that the real essence of building personal networks for INVs is their potential to open up opportunities for meeting new business partners. An entrepreneur who is actively looking for instances when he or she can help network members get introduced to new partners is likely to generate similar support for himself or herself, hence the internationalisation process speeds up.

"It is a honey jar that attracts bees. What opportunity will you bring to others? Your network will be built as much as you can provide value to others." (Interview with company C)

\section{CONCLUSIONS}

Our empirical investigation based on case studies with six Hungarian International New Ventures explored aspects of their market selection decisions, as well as the role of networks in their internationalisation. In terms of the geographical scope of internationalisation, companies in our sample showed the typical internationalisation pattern of targeting the largest developed foreign markets globally. However, there were exceptions that seemed to reflect a more gradual internationalisation model.

The reason to choose major developed markets was that prices are higher in these markets, while Hungarian wages are lower. Meanwhile, there is a diminishing gap between the level of expectations in technological quality in developed countries and in Hungary, which makes internationalisation a more possible as well as necessary choice for INVs. Targeting niche markets globally is sometimes easier as there is less noise in online marketing in a particular niche. 
On the other hand, our interviewees reported that it is challenging to provide services in many small countries - local regulations are often difficult to cope with. However, operating in niche markets, as well as in new and less regulated markets, can alleviate some of that challenge. Respondents also pointed out synergies between operations in different countries if the local cultural patterns are similar (e.g. within the CEE region or in certain developed markets).

In terms of the role of networks in internationalisation, companies in our sample provided positive evidence highlighting the decisive role of networks in all cases examined. The personal network (and knowledge) of the founder(s) was emphasised, especially in winning early clients. The scalability of the personal network-based business model was, however, questioned.

The original idea of a new business usually comes from the adaptation of international benchmarks or validating the idea through benchmarking. This was possible, as the founders of Hungarian INVs typically studied or worked abroad - usually in major developed markets - before starting up their company or had extensive (business or research) relationship with important foreign firms or universities.

In terms of how networks can actually be developed, our respondents underlined the fact that building networks is a dynamic and ongoing process, i.e. business success brings in more contacts. Furthermore, inbound marketing supports the credibility of INVs, as this activity in knowledge-intensive industries helps the introduction of the firm to new networks. Also, the "startupper community" often provides help to members of this network on a mutual basis, in terms of introduction to foreign markets, potential clients and partners.

Our results add to the body of literature on INV's market selection and the network approach to internationalisation through exploring potential patterns in a Hungarian sample of successful knowledge-intensive companies. Our conclusions provide a basis for more focused future research in an enlarged sample of Hungarian INVs, as well as open a potential discussion on comparative findings in the Central and Eastern European region. Given the special historical background of entrepreneurship in this region, further research may justify the identification of region-specific patterns in the internationalisation of INVs.

The management implications of our findings highlight the increasing opportunities of knowledge-intensive INVs to target particular niches in major developed markets, especially if the founders have previous experience in the given countries and industries. Given the decisive role of personal relationships in the targeted markets uncovered by our examination, Hungarian INVs need to intensify their involvement in international communities supporting the growth of such companies. 
Areas for potential future research, explored in our current investigation include examining the two propositions in a larger sample, potentially including INVs from other countries in the CEE region, as well as addressing additional issues like the potential leadership roles founders can perform in order to expand their personal network through involving their colleagues, or how the issue of shortage of talent can be managed through networks. The age and stages of internationalisation of INVs can also be worth examining.

There are potential avenues for further research at the macro level as well. ${ }^{2}$ Two IT companies in our sample were sold to large foreign firms, which may call the attention to a bias towards large companies in the socio-economic innovation ecosystem, and the increasing inability of the financial sector to act as an efficient intermediator of financial resources to the real economy. Still at the macro-level, the interrelatedness of the presence of INVs and their relocations to developed economies or acquisitions by foreign multinationals may contribute to the analysis of the so-called middle-income trap in CEE.

\section{REFERENCES}

Andersson, S. (2004): Internationalization in Different Industrial Contexts. Journal of Business Venturing 19(6): 851-875.

Andersson, S. - Evers, N. - Kuivalainen, O. (2014): International New Ventures: Rapid Internationalization across Different Industry Contexts. European Business Review 26(5): 390-405.

Autio, E. - Sapienza, H. J. - Almeida, J. G. (2000): Effects of Age at Entry, Knowledge Intensity, and Imitability on International Growth. Academy of Management Journal 43(5): 909-924.

Baum, M. - Schwens, C. - Kabst, R. (2011): A Typology of International New Ventures: Empirical Evidence from High-Technology Industries. Journal of Small Business Management 49(3): 305-330.

Békés, G. - Muraközy, B. (2012): Magyar gazellák. A gyors növekedésű vállalatok jellemzői és kialakulásuk elemzése. [Hungarian Gazelles: What Makes a High-Growth Firm in Hungary?] Közgazdasági Szemle 59(3): 233-262.

Bell, J. (1995): The Internationalization of Small Computer Software Firms: A Further Challenge to "Stage" Theories. European Journal of Marketing 29(8): 60-75.

Chetty, S. - Blankenburg Holm, D. (2000): Internationalisation of Small to Medium-Sized Manufacturing Firms: A Network Approach. International Business Review 9(1): 77-93.

Chetty, S. - Campbell-Hunt, C. (2004): A Strategic Approach to Internationalization: A Traditional versus a "Born-Global" Approach. Journal of International Marketing 12(1): 57-81.

Ciszewska-Mlinaric, M. - Obloj, K. - Wasowska, A. (2016): Effectuation and Causation: Two Decision-Making Logics of INVs at the Early Stage of Growth and Internationalisation. Journal for East European Management Studies 21(3): 275-297.

Coviello, N. E. - McAuley, A. (1999): Internationalisation and the Smaller Firm: A Review of Contemporary Empirical Research. Management International Review 39(3): 223-256.

2 We are grateful to one of the anonymous referees for raising this issue. 
Coviello, N. E. - Munro, H. J. (1995): Growing the Entrepreneurial Firm: Networking for International Market Development. European Journal of Marketing 29(7): 49-61.

Coviello, N. E. - Munro, H. (1997): Network Relationships and the Internationalisation Process of Small Software Firms. International Business Review 6(4): 361-386.

Czakó, E. - Könczöl, E. (2014): Critical Success Factors of Export Excellence and Policy Implications: The Case of Hungarian Small and Medium-Sized Enterprises. In: Gubik, A. S. - Wach, K. (eds): International Entrepreneurship and Corporate Growth in Visegrad Countries. Miskolc, Hungary: University of Miskolc, pp. 69-84.

Danik, L. - Kowalik, I. - Král, P. (2016): A Comparative Analysis of Polish and Czech International New Ventures. Central European Business Review 5(2): 57-73.

Daszkiewicz, N. (2014): Internationalisation of Firms through Networks - Empirical Evidence from Poland. In: Gubik, A. S. - Wach, K. (eds): International Entrepreneurship and Corporate Growth in Visegrad Countries. Miskolc, Hungary: University of Miskolc, pp. 57-68.

Dunning, J. H. (1993): Multinational Enterprises and the Global Economy. Wokingham, Berkshire: Addison Wesley.

Eriksson, K. - Johanson, J. - Majkgård, A. - Sharma, D. (1997): Experiential Knowledge and Cost in the Internationalization Process. Journal of International Business Studies 28: 337-360.

Evers, N. (2010): Factors Influencing the Internationalisation of New Ventures in the Irish Aquaculture Industry: An Exploratory Study. Journal of International Entrepreneurship 8(4): 392-416.

Fan, T. - Phan, P. (2007): International New Ventures: Revisiting the Influences behind the "BornGlobal" Firm. Journal of International Business Studies 38(7): 1113-1131.

Fillis, I. (2002): The Internationalization Process of the Craft Microenterprise. Journal of Developmental Entrepreneurship 7(1): 25-43.

Hashai, N. (2011): Sequencing the Expansion of Geographic Scope and Foreign Operations by "Born Global" Firms. Journal of International Business Studies 42(8): 995-1015.

Jarosiński, M. (2013): Contemporary Models of Polish Firms' Internationalization - Literature and Research Review. Journal of Economics and Management 13: 57-65.

Jarosiński, M. (2014): Characteristics of Polish Firms' Internationalisation Processes. In: Knezevic, B. - Wach, K. (eds): International Business from the Central European Perspective. Zagreb, Croatia: University of Zagreb - Faculty of Economics and Business, pp. 43-52.

Johanson, J. - Vahlne, J. E. (1977): The Internationalization Process of the Firm - A Model of Knowledge Development and Increasing Foreign Market Commitments. Journal of International Business Studies 8(1): 23-32.

Johanson, J. - Vahlne, J. E. (2003): Business Relationship Learning and Commitment in the Internationalization Process. Journal of International Entrepreneurship 1(1): 83-101.

Johanson, J. - Vahlne, J. E. (2009): The Uppsala Internationalisation Process Model Revisited. From Liability of Foreignness to Liability of Outsidership. Journal of International Business Studies 40(9): 1411-1431.

Johanson, J. - Vahlne, J. E. (2011): Markets as Networks: Implications for Strategy-Making. Journal of the Academy of Marketing Science 39(4): 484-491.

Johnson, J. E. (2004): Factors Influencing the Early Internationalization of High Technology Startups: US and UK Evidence. Journal of International Entrepreneurship 2: 139-154.

Jolly, V. K. - Alahuta, M. - Jeannet, J.-P. (1992): Challenging the Incumbents: How HighTechnology Start-ups Compete Globally. Journal of Strategic Change 1(2): 71-82.

Jones, M. V. - Coviello, N. E. (2005): Internationalization: Conceptualizing an Entrepreneurial Process of Behavior in Time. Journal of International Business Studies 36(3): 284-303.

Kalinic, I. - Forza, C. (2012): Rapid Internationalization of Traditional SMEs: Between Gradualist Models and Born Globals. International Business Review 21(4): 694-707. 
Kiss, A. N. - Danis, W. M. - Cavusgil, S. T. (2012): International Entrepreneurship Research in Emerging Economies: A Critical Review and Research Agenda. Journal of Business Venturing 27(2): 266-190.

Knight, G. A. - Cavusgil, S. T. (2004): Innovation, Organizational Capabilities, and the BornGlobal Firm. Journal of International Business Studies 35(2): 124-141.

Lamotte, O. - Colovic, A. (2015): Early Internationalization of New Ventures from Emerging Countries: The Case of Transition Economies. Management 18(1): 8-30.

Madsen, T. K. (2013): Early and Rapidly Internationalizing Ventures: Similarities and Differences between Classifications Based on the Original International New Venture and Born Global Literatures. Journal of International Entrepreneurship 11(1): 65-79.

Matiusinaite, A. - Sekliuckiene, J. (2015): Factors Determining Early Internationalization of Entrepreneurial SMEs: Theoretical Approach. International Journal of Business and Economic Sciences Applied Research 8(3): 21-32.

McDougall, P. P. - Shane, S. - Oviatt, B. M. (1994): Explaining the Formation of International New Ventures: The Limits of Theories from International Business Research. Journal of Business Venturing 9(6): 469-487.

Musteen, M. - Datta, D. K. - Francis, J. (2014): Early Internationalization by Firms in Transition Economies into Developed Markets: The Role of International Networks. Global Strategy Journal 4: 221-237.

Némethné Pál, K. (2010): Hol szökellnek a magyar gazellák? A dinamikusan növekvő kis- és középvállalatok néhány jellemzője. [Where do Hungarian Gazelles Leap? Selected Characteristics of Dynamically Growing SMEs] Vezetéstudomány 41: 32-44.

Nowiński, W. - Rialp, A. (2013): Drivers and Strategies of International New Ventures from a Central European Transition Economy. Journal for East European Management Studies 18(2): 191-231.

OECD (1997a): Globalisation and Small and Medium Enterprises, vol. 1: Synthesis Report. OECD: Paris.

OECD (1997b): Globalisation and Small and Medium Enterprises, vol. 2: Country Reports. OECD: Paris

Oviatt, B. M. - McDougall, P. P. (1994): Toward a Theory of International new Ventures. Journal of International Business Studies 25(1): 45-64.

Oviatt, B. M. - McDougall, P. P. (1995): Global Start-ups: Entrepreneurs on a Worldwide Stage. Academy of Management Executive 9(2): 30-44.

Oviatt, B. M. - McDougall, P. P. (2005): Defining International Entrepreneurship and Modelling the Speed of Internationalization. Entrepreneurship Theory and Practice 29(5): 537-553.

Rasmussen, E. S. - Madsen, T. K. - Evangelista, F. (2001): The Founding of the Born Global Company in Denmark and Australia: Sensemaking and Networking. Asia Pacific Journal of Marketing and Logistics 13(3): 75-107.

Rialp, A. - Rialp, J. - Knight, G. A. (2005): The Phenomenon of Early Internationalizing Firms: What do We Know after a Decade (1993-2003) of Scientific Inquiry? International Business Review 14(2): 147-166.

Rialp, A. - Rialp, J. - Urbano, D. - Vaillant, Y. (2005): The Born-Global Phenomenon: A Comparative Case Study Research. Journal of International Entrepreneurship 3(2): 133-171.

Sapienza, H. - Autio, E. - George, G. - Zahra, S. A. (2006): A Capabilities Perspective on the Effects of Early Internationalization on Firm Survival and Growth. Academy of Management Review 31(4): 914-933.

Sass, M. (2012): Internationalisation of Innovative SMEs in the Hungarian Medical Precision Instruments Industry. Post-Communist Economies 24(3): 365-382. 
Schwens, C. - Kabst, R. (2009): Early Internationalization: A Transaction Cost Economics and Structural Embeddedness Perspective. Journal of International Entrepreneurship 7(4): 323340.

Śliwiński, R. - Śliwińska, M. (2014): Growth in the Polish Fast Growing Enterprises on Foreign Markets and Its Limitations. In: Knezevic, B. - Wach, K. (eds): International Business from the Central European Perspective. Zagreb, Croatia: University of Zagreb - Faculty of Economics and Business, pp. 67-82.

Szalavetz, A. (2015): A Dynamic Capabilities Perspective of High-Growth Firms: Organizational Aspects. International Journal of Management and Economics 48(1): 45-62.

Verbeke, A. - Li, L. - Goerzen, A. (2009): Toward More Effective Research on the Multinationality-Performance Relationship. Management International Review 49(2): 149-162.

Vissak, T. (2003): The Internationalization of Foreign-Owned Enterprises in Estonia: An Extended Network Perspective. PhD dissertation. Tartu, Finland: Tartu University Press.

Vissak, T. (2004): The Importance and Limitations of the Network Approach to Internationalization. 20th IMP-conference in Copenhagen, Denmark, https://impgroup.org/uploads/papers/4607.pdf, accessed 04/07/2017.

Vissak, T. (2007): The Emergence and Success Factors of Fast Internationalizers. Journal of EastWest Business 13(1): 11-33.

Vissak, T. (2010): Recommendations for Using the Case Study Method in International Business Research. The Qualitative Report 15(2): 370-388.

Welch, L. S. (2015): The Emergence of a Knowledge-Based Theory of Internationalisation. Prometheus 33(4): 361-374.

Zapletalová, S. (2015): Models of Czech Companies' Internationalization. Journal of International Entrepreneurship 13: 153-168.

Zbierowski, P. (2014): Determinants of Early Internationalization - Empirical Evidence from Global Entrepreneurship Monitor. In: Knezevic, B. - Wach, K. (eds): International Business from the Central European Perspective. Zagreb, Croatia: University of Zagreb - Faculty of Economics and Business, pp. 27-42.

Open Access. This is an open-access article distributed under the terms of the Creative Commons Attribution 4.0 International License (https://creativecommons. org/licenses/by/4.0), which permits unrestricted use, distribution, and reproduction in any medium, provided the original author and source are credited, a link to the CC License is provided, and changes - if any - are indicated. (SID_1) 